\title{
Henry George Dunn (1917-2008) A Gentleman and a Scholar
}

Henry Dunn, who died on December 9th, 2008, was indeed a gentleman and a scholar. A man of unfailing courtesy, he brought an old world charm to all professional and social occasions. Born Heinz Georg Danziger on 18th April 1917, he grew up in Leipzig, Germany, and in 1935 emigrated with his brother to England to study at Baddingham College in preparation for taking the entrance examination for Cambridge. Henry had a great facility with languages, which enabled him to perfect his English and pass the certification examination six weeks after arrival in England.

He entered Trinity College, Cambridge, and obtained his B.A. in 1938 and his M.B., B.Chir. in 1942. Henry's medical career was interrupted because both he and his brother, Walter, were considered aliens during the war and were interned in a camp in Australia, where Henry became fluent in Italian at His Majesty's expense. Henry had a very eclectic postgraduate training. He joined the Royal Army Medical Corps in 1944 at which time he changed his name to Henry George Dunn. He served in India from 1944 to 1946 and rose to the rank of major. Henry's father was a dermatologist and Henry became a "supernumerary first assistant in dermatology" at the London Hospital in 1947. However, he made the cardinal error of bringing out a stethoscope to listen to a patient's chest much to the chagrin of the ward sister who deemed such behaviour inappropriate and it was suggested that his future might lie in other fields. He was appointed as a house officer and then registrar in paediatrics at the London Hospital and thereafter at Hospital For Sick Children at Great Ormond Street Hospital in London between 1948 and 1951. His next career step was as an assistant pathologist at the Babies' Hospital, Columbia Presbyterian Medical Center in New York, where he studied under Dorothy Andersen, a research pathologist who had discovered cystic fibrosis and had a major interest in congenital heart disease. He subsequently joined his parents and brother in Vancouver and became Chief Resident in Paediatrics at the Vancouver General Hospital in 1953 - 1954. After a brief sojourn in general pediatric practice, Henry was recruited to the academic staff of the Department of Pediatrics at the University of British Columbia in 1956.
It was in Vancouver that Henry met his perfect match in Erica, who had come from England via Montreal to nurse in a polio ward in Vancouver. Erica is an equally extraordinary character who combines her English charm with a wonderful sense of humour and provided the bedrock on which Henry's career moved forward. Her botanical skills were highlighted at their cottage on Saltspring Island where they spent much of the summer with their children, Tony and Jenny.

Henry had the unique distinction of publishing in peer-reviewed journals in seven consecutive decades. His first paper was in the Journal of Obstetrics and Gynaecology of the British Empire in 1944 on recurrent anencephaly. His 122 papers covered a wide variety of topics but his particular interests were the neurometabolic diseases, Xlinked mental retardation and electrodiagnostic studies in children. His major study was on the physical, intellectual and social sequelae of low birth weight on which he wrote ten papers and a book. His final paper was published in the Canadian Journal of Neurological Sciences in 2002 on Rett syndrome and described the positron emission tomography findings in this disorder.

Henry served on the council of the Canadian Neurological Society and played an important role in the founding of both the Canadian Association of Child Neurology (CACN) and the Canadian League Against Epilepsy (CLAE). Henry initiated the move to combine the neurologists who had an interest in pediatrics with the pediatricians who had an interest in neurological disorders. This resulted in the formation of the Canadian Association of Child Neurology in June 1971 (for which the annual fee was $\$ 2$ !) at a meeting in Kingston, Ontario, at which he was elected the first President. Negotiations with the Royal College of Physicians and Surgeons of Canada resulted in modification of the training regulations and examinations in neurology that would permit certification of trainees specializing in pediatric neurology. The examination board was modified to include a pediatric neurologist and Henry was the first pediatric neurology examiner from 1975 to 1978 . The CACN annual meetings alternated initially between the Canadian Congress of Neurological Sciences (CCNS) and the Canadian Pediatric Society meetings until 1978 and the CACN became affiliated 
with the CCNS in 1981. The formation of the CLAE was discussed at a meeting of the CCNS in London, Ontario in 1975. Dr. Juhn Wada led the initiative and the other founding members with Henry included Drs. Norman Auckland, Frederick Andermann, Warren Blume, Keith Meloff and Alan Sherwin.

Henry played a major role in the training of many child neurologists around the world. In addition to Canada and the United States, trainees were attracted from England, Ireland, Sweden, Israel, Saudi Arabia, Hong Kong, New Zealand and Argentina. Henry's meticulous approach and attention to detail were characteristics that his students strove to emulate. On one occasion, a neurology fellow presented a young boy who had had an epileptic seizure that had occurred shortly after breakfast. When Henry enquired what the boy had eaten at breakfast, the fellow was wise to Henry's idiosyncrasies and replied that he had eggs, whereupon Henry continued "Yes, and how were the eggs done?"
At his memorial service, his daughter, Jenny, spoke of the qualities that characterized Henry: his love of learning that led him to be limited to visiting one cathedral a day when travelling in Europe; his calm, unflappable manner that resulted in him never raising his voice; and a saying by Rabindranath Tagore that epitomized his life and that he loved to quote, "I slept and dreamt that life was joy. I awoke and saw that life was service. I acted and behold, service was joy." 